\title{
PROCEEDINGS
}

\author{
ON THE OCCASION OF
}

LAYING THE CORNER-STONE

OF THE

\section{NEW HALL}

OF THE

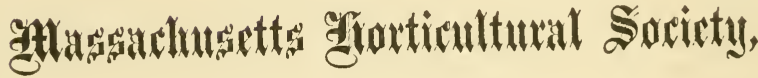

A U G UST 18, 1864 .

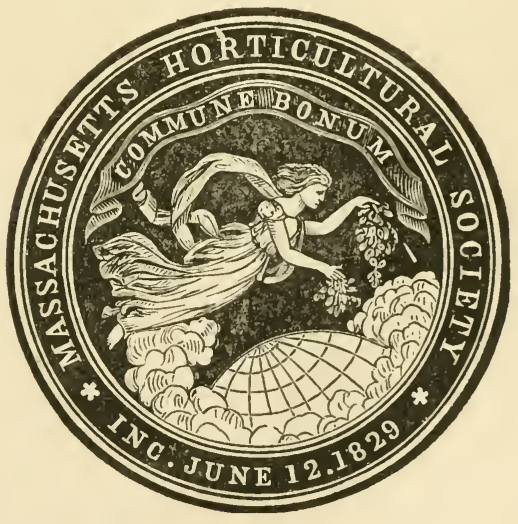

B O S T O N :

HENRY W. DUTTON \& SON, PRINTERS, 90 and 92 Washington StREeT.

1864 . 


\section{UNIVERSITY OF MASSACHUSETTS}

\section{AT AMHERST}

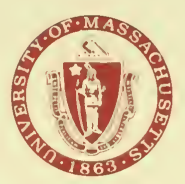

\section{UNIVERSITY LIBRARY}

Special Collections \& Rare Books

\begin{tabular}{|l|}
\hline Spec. \\
Coll. \\
SB \\
21 \\
M5 \\
M47 \\
1864 \\
\end{tabular}




\section{detissanchusetts dorticultural society.}

At an adjourned meeting of the Massachusetts Horticultural Society, held at their rooms, Saturday, September 3, the following votes were unanimously passed:

That the thanks of the Society be tendered to the President, for his very interesting and felicitous address delivered at the laying of the Corner-Stone, and that a copy be requested for publication.

That the thanks of the Society be presented to the Rer. Dr. Lothrop, for his services at the ceremony of laying the CornerStone.

That the Committee of Publication be authorized to publish, for distribution among the members, the address delivered by the President, C. M. Hover, at the laying of the Corner-Stone of Horticultural Hall, on the 18th of August last, together with a detailed account of the ceremonies on that occasion.

$$
\text { C. M. HOVEY, President. }
$$

F. LYMAN WINSHIP, SECretary. 


\section{PROCEEDINGS.}

The Corner-Stone of the New Hall of the Massachusetts Horticultural Society was laid on the 18th of August, 1864.

At a Special Meeting of the Society, called on the 13th day of August, at the Rooms in Amory Hall, the President stated that the work of building the new Hall had so far progressed as to be in readiness for laying the Corner-Stone.

He remarked that the magnitude of the building was such, that it was deemed proper to observe the occasion in a manner commensurate with the importance of the work; and, although it was not the desire of the Building Committee, or he presumed of the Society, to make any ostentatious display, yet it was thought some notice should be taken of such an event, and that the Corner-Stone should be laid with such ceremonies as were deemed appropriate. It remained for the Society to take such measures as would render the occasion interesting to the members and creditable to the association.

On motion of G. W. Pratt, Esq., it was voted that a Committee of ten be appointed by the President, with full power to make all necessary arrangements thought proper for the occasion, and the following gentlemen were appointed the Committee :

Geo. W. Pratt,

S. H. Gibbens,

W. H. Spooner, Jr.,

WiLLiAM GRAY, JR.,

C. Н. В. Виеск,

F. Lyman Winship,

J. C. Hover,

D. T. Curtis,

E. W. Buswell,

R. McCleary Copeland. 
Agreeably to the arrangements made by the Committee, the members of the Society, with His Honor Mayor Lincols, the members of various kindred societies, and other invited guests assembled at the Rooms of the Society, in Amory Hall, at the corner of West and Washington Streets, at 9 o'clock, A. M., on the 18th of August. The meeting was opened by the President, who stated its objects and requested those present to form in procession in the Hall, and thence under the marshalship of Sayuec Hatch, Esq., proceed to the site of the building, at the corner of Tremont and Bromfield Streets. The Order of Procession was as follows:

\section{Detachment of Police.}

Chief Marshal.

Brigade Band.

Committee of Arrangements.

President of the Society and Chaplain.

His Honor the Mayor, and Members of the City Government. Building Committee.

Stewards bearing the Boxes and Documents for deposit beneath the Stone.

Arehitects of the Building.

Past Officers of the Society.

Invited Guests.

Members of the Massachusetts Charitable Mechanics' Association.

Members of the Natural History Society.

Trustees of Mount Auburn Cemetery.

Members of the Massachusetts Historical Society.

Members of the Institute of Technology.

Trustees of the Public Library.

Members of the Massachusetts Society for Promoting A griculture.

Members of the Boston Numismatic Society.

Members of the Massachusetts Horticultural Society.

The Procession proceeded up West Street, through Tremont Strect Mall and Tremont Street, to the site of the new building, 
and formed upon the platform, a raised dais being erected for the President, Chaplain, and invited guests. After Music by the Band, the following Address was delivered by the President of the Society. 


\section{ADDRESS.}

DELIVERED BY C. M. hOVEY, ESQ., PRESIDENT OF THE SOCIETY.

\section{Gentlemen of the}

\section{Massachusetts Horticultural Society:}

We are assembled here to-day, agreeably to your direction, to take the first formal step towards the erection of a building for the use of the Society, to more effectually carry out its purposes of "encouraging and improving the science and practice of Horticulture, promoting the amelioration of the various species of trees, fruits, plants, and vegetables, and the introduction of new species and varieties."

Such were the original objects of the Society, as named in the act of incorporation, and such, I' am happy to say, they have always been, and I doubt not, ever will be, as long as this beautiful edifice you are about to erect shall endure.

This is the second time that you have, in the course of your organization, erected a building for the Society. It will be just twenty years, on the 14th of September next, since the Corner-Stone of Horticultural Hall in School Street, erected on the site of the old Latin school-house, was laid by your late President, the Hon. Marshall P. 
WiLder, now prevented from uniting in these ceremonies by long continued illness. It was the only important act of the Society since its foundation in which I have not been present or taken a part; but absence abroad prevented me from witnessing the services on that interesting occasion; and I esteem it a source of the highest gratifcation that, through your continued kindness and great confidence, I have now the honor not only to be present with you, but to take so prominent a part in laying the corner-stone of another and more magnificent structure, which will undoubtedly be the home of the Society long after we and many succeeding generations have passed away.

The Massachusetts Horticultural Society was organized February 24th and incorporated June 12th, 1829, and it is highly gratifying to me, and I doubt not to every member, to recognize among those who are assembled here today, gentlemen whose names are borne upon the charter, and many others who were prominent and active members the first year of its organization. Though thirty-five years have glided away, and age may have lessened their active labors, it has not checked their enthusiasm, diminished their zeal, or lessened their devotion to the interests of a pursuit which, in their younger days, was a source of instructive occupation and pleasure, and which now amuses and solaces their declining years.

It would scarcely be possible, should I make the attempt, in these brief remarks, to recount the progress of 
the Society, from its small beginning in State Street, up to that period when the old hall in School Street was erected, since which time its history is more familiar; but I should be recreant to duty did I not, standing on these solid foundations, refer to one who did more than all others to place the society in its present flourishing condition, and enable it now to undertake the building of an edifice of such magnitude and architectural beauty. Need I say I refer to the late General Dearborn? Without detracting in the least from the labors of a band of intelligent and distinguished men, who were pioneers in the enterprise, it is not too much to say that to him are we indebted for that "sacred garden of the dead," Mount Auburn Cemetery, and the consequent results from his plan of an experimental garden. His enlarged knowledge, liberal views, accomplished mind, practical skill, and elevated character, alone carried the project through. His pen was never idle in gathering facts and writing reports to show the undertaking a safe one, and the objects to be attained worthy the consideration of the whole community. By the happy combination of an experimental garden and cemetery, horticulture was to be recognized as an art and science, and the dead removed to secluded and shady groves, away from the busy marts of crowded cities; and though a combination of circumstances changed a part of his favorite scheme, it is undoubtedly owing to its failure that we are indebted for the means to erect this Temple, no less calculated "to foster and extend a taste for the pleasant, useful, 
and refined art of gardening." We love and revere the name of such a noble man: we shall never forget his unselfish labors, and, when our edifice is completed, it will, I am sure, be the hope that his statue may have a prominent place within it. But whether statue or bust shall ever grace our hall, this building will be the enduring memorial of his genius and services, and his name will be held in grateful remembrance by a thousand generations.

But it is since the completion of the former hall that the progress of the Society has been more rapid, and its influence felt throughout the entire country. New life and fresh vitality were infused into the Society. It had the sympathy, as it had the substantial aid, of the public. It was appreciated as its founders intended it should be. Its objects seemed all at once to become apparent. It encouraged and promoted the science and practice of horticulture;-it stimulated the production and introduction of new flowers, fruits, trees, and plants;-it rewarded the cultivator for the best specimens of his skill;-it gathered together, for the use of the members, a library of the most celebrated English and French works on gardening; -it made known through its weekly and annual exhibitions all the choicer productions of the garden, the orchard, and the greenhouse; -it awakened a taste for ornamental and landscape art, and it disseminated through its annual reports a vast fund of information upon every branch of horticulture. 
Who does not see, in whatever direction he may turn, the results of the influence which has gone out from the Massachusetts Horticultural Society? Beautiful villas enrich and embellish all parts of the country; suburban gardens of greater or less extent give a cheerful and picturesque aspect to our torns and villages; and even the little gardens and city lots denote some unseen influence which has changed these weedy and neglected places into verdant and fertile spots. Who will compare the rural aspect of the country thirty-five years ago with its present appearance, and say the Massachusetts Horticultural Society has wasted the resources with which a liberal public have in part endowed it, for objects so beneficent, and for purposes which confer both individual comfort and happiness upon the people.

Thanks to the generous men of Boston, that after they had witnessed our good stewardship, they reposed every confidence in us, and came forward liberally with their aid, determined that no loss should come from an enterprise then deemed hazardous for our means. Yes, gentlemen, we were the owners of a new hall, but beyond that we had but little to accomplish the great objects in view, namely, to create a laudable competition by the offer and distribution of liberal prizes, and thus attract the people to see the superior specimens which the skill of our cultivators could produce. We had not, fortunately, any occasion to wait; and I deem this a most fitting opportunity to allude to their liberal acts. Few of the large number of mem- 
bers, who have recently joined us, know by what means we have reached our present prosperity, and, if they did, we should be ungrateful were we to forget those among the dead, or those among the living, to whom we are indebted for aid to more effectually carry forward the great objects of our association.

This building, it is true, is erected by the funds of the Society principally received from our interest in Mount Auburn Cemetery. This beautiful location, however, was only secured by the most persevering efforts of the committee appointed for that purpose, who believed it possessed all the facilities the Society required, and was just within the means of the Society to purchase. Two years have your committee assiduously labored to bring the work to its present state. We hope and believe the Society will never have cause to regret what they have done.

And we have established funds, the income of which is distributed yearly in premiums. This has been the life of the Society; and, the larger the amount at our disposal, the more rapidly will the art of Horticulture be promoted, and a genuine taste for gardening be encouraged.

And now let me name, because first, and just at the right time, just as we had expended our funds in the building of the old hall, came the liberal donation of the venerable merchant, Samued Appleton, whose many benefactions to various public institutions will render his name honorable, and cause his memory ever to be cherished. 
Next, we have the same generous gift from the public spirited and well-known gentleman, the son of one who presided at the first formal call to organize the Society, and whose name is intimately associated with everything connected with the early improvements in horticulture around Boston. Need I name John A. Lowell? "Not being" able," as he says in his letter to the Society, "to actively coöperate with you, but wishing to contribute in a moderate way, I send you one thousand dollars." May he long be spared to witness the good results of his timely aid.

And now, standing conspicuously in the group of our many benefactors, we have another name, not only associated with horticulture and agriculture, but with the finer art of landscape gardening. Who does not remember the once and yet elegant demesne at Waltham, where, years gone by, the beautiful deer might be seen bounding o'er the lawn, or gently reposing beneath scme graceful elm? Need I name Theodore Lyman, Jr.? who bequeathed to us the munificent sum of $\$ 10,000$, having during his life made the same generous gift as those already named. His memory will be ever dear to us and our successors.

And yet we have the aid of that kind-hearted and liberal merchant, Josiah BradLeE, whose aim it was to see the effects of his liberality during his own life. Not only was his donation of one thousand dollars most gratefully received, but his many acts of friendship towards the Society, in its time of need, are indelibly recorded in our memory. 
Then we have the legacy of one who was among the earliest friends of the Suciety, always an active and honorable member, and for many years one of its Vice Presidents; whose special and successful culture of one of our most valuable fruits has been of great service to pomological progress. The appropriation of the income of the French fund to the encouragement of one particular fruit, has already been highly beneficial, and the yearly exhibition of superior specimens of apples will always remind us of his early and later participations in the prominent acts of the Society.

Others among those who have gone from us, and whose ashes repose beneath the fragrant turf, or lie beneath the shady groves of Mount Auburn, have made us participators of their bounty. Each and all will be remembered by every member of our association.

But, gentlemen, there is one at least among the living who has given us recently and so liberally,-encouraging us by his sympathy and devotion to our interests, - that I think I shall not be transgressing the bounds of friendship to mention. I refer to H. Hollis Hunnewell, whose beautiful country residence at Wellesley so many of you have seen and admired, and which displays so much taste in its arrangement and keeping. His generous gift of $\$ 2500$, just now that we wish to increase rather than curtail our premiums, is most opportune. Mr. Hunnewell is now absent in Europe; and from these foundations we 
waft across the broad Atlantic our best wishes for his health and prosperity, and a safe return to his home.

Of other donors it would be a pleasure to speak, but 1 am not permitted to do so.

But the most colossal edifice which associated wealth could erect, though it might be a perpetual monument of architectural taste and skill, would be of little avail without the aid of a zealous and coöperative association; and while we recount with pride these many benefactions, we ought not to forget that to a host of intelligent amateurs and cultivators-to Cook, Downer, Lowell, Manning, Kenrick, Winship, Perkins, Prince, Phinney, Cushing, Yose, Walker, Lovett, Harris, Teschemacher, Haggerston, Wiltiams, and many others-not to enumerate the living-are we indebted for the invaluable services and unflagging zeal which have given to the Society a renown second to no other horticultural association in the world.

And now, gentlemen, as we are to place beneath this granite block the records of what we have already accomplished, with the object of transmitting them to distant generations, let us hope that, whenever, at some very remote day, when these walls may crumble and decay,-for decay, though slow, is the destiny of all earthly things, - and these memorials shall come to light, they will at least serve to show that the objects of the Society were solely to promote all those pursuits which bring pleasure and happiness to the social and domestic life; to enrich and embellish our homes and country; to create a refined taste, and to 
open new and exhaustless sources of instruction and wealth.

With the increased means with which the liberality of the public have in part endowed us, - the resources from the investment now believed to be so judiciously made,and the greater facilities afforded by this edifice, we shall be called upon for fresh exertion, greater activity, and the same persistent zeal which have thus far given us a name and reputation at home and abroad.

We feel the responsibility of the task, but an appreciating and enlightened public will cheer us on; and as those who have been so prominent in our councils are soon to pass away, and the "places which know them shall know them no more," may our successors, animated with their zeal, stimulated by their example, roused by their energy, and enlightened by their knowledge, not only preserve the Society in its present flourishing state, but extend its usefulness, increase its popularity, and give it an imperishable renown.

At the elose of the $\Lambda$ ddress, the Corner-Stone was laid by the President, who was presented with an elegantly burnished stecl trowel for the occasion.

An appropriate prayer was then offered by the Rev. Dr. Lothrop, Chaplain.

The whole audience then joined in singing Old Hundred, after which, the ceremonies were concluded with a Benedietion. 
APPENDIX. 



\section{APPENDIX.}

DESCRIPTION OF TIIE BOX, PLATE, AND OTHER ARTICLES, DEPOSITED UNDER TIE CORNER-STONE OF TIE NEW HALL.

The box is made of zine, and twelve inches long, ten wide, and four deep. In the box the annexed list of articles are enclosed :

1. A Silver Plate, measuring eight inches long and six wide, upon which the following is engraved:

THIS EDIFICE IS ERECTED

BY THE

\section{datasartustts dorticultural sorirty,}

For the purpose of encouraging and improving the Science and Practice of IIorticulture,

And this Corner-Stone laid, August 18, 1864, BY THE PRESIDENT,

CHARLES M. HOVEY.

Building Committee:

C. Mr. Hover, Josiah Sticknex, M. P. WILDER, C. U. Whithore, IV. IR. Acstix,
H. H. HuNNEWELL, Joseph S. CABot, J. F. C. IYDE,

I. Wetherell.

Architects :

Grideey J. F. Bryant axd Artier Gibman.

To this Society the community are indebted for the foundation and consecration of Mount Auburn Cemetery. 
Masicilusetts Horticultural Societr,

Incorporated the 12 day of June, A. D. 1829.

Present number of members, six hundred eighty.

President,

CHARLES M. HOVEY.

Vice Presidents,

J. F. C. HYde,

C. O. Whitmore,

H. Hollis Huxvewell,

IV. C. Strong.

Treasurer,

William R. Austin.

Corresponding Secretary,

Eben. Wight.
Recording Secretary,

F. LYMAN WINSHIP.

2. Proceedings of the Society, from 1843 to 1864 .

3. Publications of the Society, containing its History, \&c., by Gen. Dearborn.

4. Boston Almanac for 1864.

5. Catalogue of Proprietors of Mount Auburn Cemetery.

6. Copies of Hovey's Magazine of Horticulture for 186t, containing Reports of Building Committee.

7. Copy of Fruits of America.

8. Boston newspapers of August 18.

9. Silver Medal of the Society.

10. Bronze Medal.

11. Appleton Bronze Medal.

12. Coins of the United States, dollar, half dollar, and smaller, of the date of $186 t$.

Beneath the box was placed the box, with its contents entire, which was taken from beneath the Corner-Stone of the old Hall in School Street.

Both boxes were placed in a cavity in the first rermiculated stone, at the north-west corner of the building, on Tremont Street and Montgomery Place. 


\section{REPORT OF THE BUILDING COMMITTEE.}

At a quarterly meeting of the Society, held January 2, 1864, on motion of C. O. Whitmore, a Committee of Nine, of which the President should be Chairman, was appointed to consider the expediency of erecting a building on the Montgomery House estate, and report the probable cost of the same.

Tine President,

Josiah Stickney,

C. O. Whituore,

M. P. Wilder,

J. S. CABOT,

W. R. Austin,

H. H. HuNNEWELL,

J. F. C. HYDE, and

L. Wetmerell,

were nominated and unanimously chosen.

At the meeting of the Society, February 6th, the Building Committee made the following Report:

The Committee to whom was referred the subject of the expediency of erecting a building on the Montgomery House estate, recently purchased by the Society, and the probable expense of the same, have attended to that duty, and submit the following Report:

Your Committee consider the subject referred to them of very great importance to the Society, and they have endeavored to give it the thorough deliberation and investigation its importance demands. A portion of the Committee having previously examined the subject and made a general report, they were desirous that other gentlemen, fresh from the Society, should coöperate with them, and carefully examine the whole question of building, and give such an opinion as would enable every member to east a satisfactory vote when brought before the Society. 
Your Committee believe it is for the permanent interest of the Society to proceed with the erection of a building, if it can be done within its means, or with safety as an investment of its funds. The question of time is one which they have given much attention, and looking at it in all its aspects, they feel assured, with such a plan as they have had prepared, should it meet the wishes and approval of the Society, a building can be erected at a reasonably enhanced price, without detriment to its present interests or future welfare, afford a good income upon the outlay, and, what is of most importance, place the Society in the possession of a hall of its own, where it can accommodate all the exhibitions, weekly or annual-a building that shall be an ornament to our city, "a fitting testimonial of our liberality"-and one which will enable us to carry forward the great objects of its founders, viz.: "Encouraging and improving the science of horticulture."

At an early stage of the action of the Society, a committee of five was chosen to purchase a suitable site within certain limits; and that committee, desirous of serving the interests and forwarding the objects of the Society, which they believed to be to secure a handsome and appropriate building, selected the Montgomery House estate, and had plans and estimates prepared by G. J. F. Bryant, Esq., placed before them and the Society. 'This plan has been taken as the basis of another, now about to be submitted for your consideration. No rote was taken upon it by the old Committee, and its internal arrangements were not especially criticised or debated, as the time had not then arrived for such action. It was simply an idea of the style of building, in its architectural proportions and general beauty. Estimates were, howerer, made, showing that it could have been erected in 1862 for $\$ 85,000$.

This plan has been materially and essentially altered in its interior arrangements, while its exterior character has been preserved, and, it is conficlently hoped, its architectural proportions improved, its fitness angmented, and its beauty of derign much enhanced. It is now presented, with the full belief that, after much study, it comes as near as possible to the wants and 
requirements of the Society, both as regards its own u=es and that equally important one of income. It has hat the long attention and deliberation of some of the Committee, and is offered with the hope and expectation that it will be satisfactory to all.

The plan herewith presented contains a larger and smaller hall ; the former suited to the Opening, liose, and Anmual Exhibitions, or any exhibitions the Socicty may wish to make; and the latter admirably adapted to its weekly and ordinary shows. On the second floor, the meeting room, library room, and committee rooms connect with the smaller hall, with a rear entrance from Montgomery Place for exhibitors, and a convenient room for preparing plants and fruits for exhilition. The large hall occupies the third floor, and the space of the entire building, accessible by two broarl flights of stairs, from the rotunda, and also a rear entrance firom Montgomery Place, and the same accommodations for exhibitors as the hall bencath. It will be a lofty and magnificent hall, with a gallery at one end and a stage at the other, and will be lighted from the sides and top. Its area will be about 4000 feet. The street floor contains two large stores on Tremont Street and four on Bromficld Street, with three basement stores beneath.

Your Committee do not think it necessary to enter into any particular description of the exterior design of the building. The various drawings of the front and side façades, as well as the perspective view, now placed before you for your inspection and approval, relieve them of that duty. The style is that now generally adopted in modern Europe, for most of the publie edifices of this character, and from its graceful proportions, harmonious expression, and adaptability to greneral use, appears best suited to the requirements of the Society, while it affords the best evidence of our appreciation of architectural beauty.

The material selected by your Committee is the Concord white granite, which, for its tone of color and durability, preeminently fit it for the style and purpose of such a structure. The best example of this material, of recent erection, is the new City Hall, and one of much earlier late, the house of David 
Sears, E*r., on Beacon Street, the latter best illustrating its wear and appearance after the lapse of nearly half a century.

The entire cost of the erection of the building, according to the estimates of Mr. Bryant, made to your Committee and procured from responsible parties, and since revised, will not exceed $\$ 102,500$, and when the offers are open to competition he believes it will be reduced. When your Committee take into consideration the greatly enhanced value of its stocks, over that of 1862, this excess over the estimates of the first plan is far more favorable than they were led to anticipate.

The income of the building, according to the best judgment of your Committee, and obtained by careful enquiry of the income of property in the immediate vicinity, will be fully equal to six per centum per annum on the entire cost of the investment.

To meet the cost of the erection of the building, your Committee herewith annex a statement of the assets of the Socicty arailable for that purpose, very carefully and accurately prepared by your Treasurer, and believed to be correct, amounting to $\$ 100,054$ on the $23 d$ January last.

To meet the payment of the mortgages upon the estate, payable in twenty years from September 1, 1863, it is proposed by your Committee to recommend to the Society, immediately upon the completion of the building, the creation of a sinking fund, which shall meet its liabilities in 1883. This proposition is to lay aside every year $\$ 3500$ from the income of Mount Auburn, which will, with interest, amount in sixteen years to $\$ 98,745$.

The deep interest which will be created by the erection of a new building, it is believed by your Committee, will greatly increase the number of members; and the income from this source and its exhilitions will probably be sufficient to pay the ordinary expenses of the Society; and should this hope be realized, a larger sum can be added to the sinking fund, should the Society so direct, which will enable it, should the opportunity offer, which it is thought possible it may, to pay off some of the mortgages (being made to six parties) before the period of their 
expiration, or leave to the Society a much larger sum to encourage the objects to which it is especially devoted.

Your Committee camnot here omit to contrast the present condition of the Society with its condition in 184:3, when it decided to purchase the old Latin Schoolhouse in School Street, for the sum of $\$ 18,000$. With only $\$ 15,000$ of available funds for the purpose, it then almost unanimously voted to ereet a building upon the site, which, with the land, would cost about $\$ 40,000$. If the attempt to build now ean be termed a hazardous enterprise, with its increased means, much larger number of members, and the far greater general public taste for horticulture and rural art, what must the action of the Society have been deemed in 1843 ? Its prospective income could not then be considered, at the outside, at more than $\$ 2500$, and the income from the building less than five per centum; and to carry forward the work it was necessary to execute a mortgage for $\$ 15,000$, besides the use of all the income from Mrt. Auburn for four years. Tet it went on prosperously, meeting all its liabilities promptly, distributing very liberally of its means for the encouragement of Horticulture and Pomological Scienee, and. thanks to those who labored so faithfully, we are now receiving the benefits of the sound judgment and foresight, united with the zeal and energy of those who laid the foundation of our success, and gave to the Society extended influence and the means of far greater usefulness.

In conclusion, your Committee would advise the immediate erection of a building worthy of that art and science which is heneeforth to be its home, and spread therefrom its benign influence throughout the land.

Who that treads the shady paths and winding arenues, or reclines beneath the sacred groves of that garden of graves, the ineeption of the founders of the Society-or surveys the broal expanse of cultivated country now reaching to the Pacific, teeming with rich fruits and beautiful flowers, would wish, with the means at our command, and the known public spirit, to erect a lesser monument to the triumphs of civilization. 
How consoling the reflection that, when we have finished our earthly work, and our ashes repose beneath the green turf and leafy bowers of Mt. Auburn, this elegant building shall be the enduring memento of the intelligenee and wisdom which formed that sacred garden of the dead, away from the busy haunts of the living. In this temple, dedicated to the elegant art of hortieulture we shall transmit to our successors a record of our earnest labors to accomplish the two-fold task of decorating and beautifying our homes while living, and of adorning and consecrating our homes in death.

Entertaining these views your Committee would recommend the passage of the following Resolutions:

Resolved, That the present Committee be constituted a Building Committee, and that they be, and are hereby authorized and direeted to proeeed with the erection of a building on the Montgomery IIouse estate, recently purchased by the Society, according to the plans, specifieations, and estimates, prepared by Gridley J. F. Bryant, Esq., approred by the Committee, and now submitted to the Society, and that they have full power to enter into and make all contracts and agreements, in the name of the Society, necessary for the erection and completion of said building.

Resolved, That the Committee now having in charge the Montgomery House estate be authorized and direeted to terminate the present lease on the first of May next.

C. M. HoveY,

Josini StickNeY,

Marsialle P. Wilder,

C. O. Whithole,

War. R. Austix,

II. II. Hunveweld,

Janis F. C. Hrde,

LeANdER WeTHERELL,

Joserte S. Cabot,

Boston, Fев. Gтн, $186 t$.

Committee on Building. 
Mr. N. Matthews moved as a substitute, in the place of the Committee's resolutions, the following, which was unamimously adopted :

That the whole matter of erecting a building be referred to the Committee, with full power to make such alterations in the plans and sipecifications as may suggest themselves, under the superintendence of the architect, Mr. G. J. F. Bryant, and at a cost not exceeding the sum of $\$ 105,000$.

\section{GENERAL DESCRIPTION OF THE BLILDING.}

The new Hall of the Massachusetts Horticultural Society occupies a central and commanding position on Tremont Street, letween Bromfield Street and MIontgomery Place. A cellar story, partially finished into apartments as a basement, covers the whole area of the estate, and includes also, all the area beneath the sidewalks, in front of the several façacles of the building. This story is sub-divided into six apartments, two of which are cellars beneath, and connected with the two front stores on Tremont Street. Three others are designed for stores or mechanical workshops, while the sixth apartment is appropriated as an engine and boiler room for the heating apparatus, and with ample accommorlations for the necessary fuel. An easy staircase in the north-east corner of this story, communicates with the stories above, as well as with the cutrance doorway on that side, from Montgomery Place. Beneath the sidewalk pavement, on this side, are located the lavatories, water closets, and urinals, for the use of the occupants of the basement, and of the stores above. All the apartments of the basement are entered from the Bromficld street fiont, by flights of steps, and all are amply lighted by upright windows in the external walls, and by Hyatt lights, to be located in the sidewalks of all the streets. 
The first, or street story, is sub-divided into the same number of compartments as those above described in the basement, and consists entirely of shops or stores, two of which front on Tremont Street, with light on the front, and on one side of each store, while the remaining four all entered from Bromfield Street, and are lighted both in front and rear of each. The stairease, commenced in the basement, is continued up through this story, and is accessible from the Montgomery Place side of the building. The front or main stairease, 10 feet in width, is carried up between the two stores on Tremont Street.

The second story contains one of the Exhibition IIalls, spanning the width of the estate, and lighted by three large windows in each of its two sides. Besiles this hall, there are four apartments to the west of it, receiving light from the three sides of the building, and communicating with each other, and with a square lobby, containing three noble flights of stairs. One of these flights leads up from the principal front entrance on Tremont Strect, and the two others are for connection with the third story, which contains the principal hall of the building. Of the four apartments on the front of this story, the two which extend across the whole of the Tremont Street front, are for the purposes of a Library, and of Superintendent's and Treasurer's office, and are connected by wide folding doors, so as to be thrown into one, when necessary. Connected with these two front rooms, are the two smaller rooms, located between the front rooms and the IIall, and occupying all the remaining space of this floor not devoted to lobly and staircases. From one of these smaller rooms, opens a water-closet and lavatory, intended for the use of the officers of the Society. To the east of the IIall on this second story, and placed between it and the extreme east wall of the estate, on the Bromfield Street side, there is an apartment of suitable size to be used as an ante-room, and corresponding in area with the staircase hall on the other side, through which runs up the continuation of the staireases of the two stories beneath, and accessible fiom Montgomery Place. Between these two is formed a recess for the stage or platform at the upper end of the hall, and a passageway in the rear of 
this recess connects the ante-room with the private stairease just described. All the apartments on this story are abundantly lighted, in the three exterior walls, by windows of liberal dimensions and pleasing proportion.

The third or upper story is mainly devoted to a principal Exhibition Hall, extending orer nearly its whole area, inasmuch as it not only spans the whole wilth of the estate, but occupies, with its lobby entrances and stair landings, the whole length of ${ }^{\circ}$ the entire property - with the exception of an ante-room, private staircase, and passageway of communication in the rear, the same as those already described on the story underneath. On account of the greater height on this floor, this arrangement of stairway, passage and ante-room is also duplicated in a secondary or half story, introduced above the one just named; the two oceupying together, only the height of the larger Hall. The lobby entrances and stair landings at the front or west end of the building, as well as that portion of the area of the large hall lying between these lobbies, are constructed so as to be ten feet in height, and over them all is a Gallery of the whole width of the IIall, and entered from one of the landings by a flight of Gallery stairs, placed in the south-west eorner of the building.

Each of the two halls, in the second and third stories, contains a stage at its eastern end, accessible from the ante-rooms, and from the rear or private staircase at that end of the Hall.

The amount of interior area and accommodation afforded by the several floors of the building, will perhaps be better understood by the following schedule of the number, designation, and dimensions of the halls, apartments, \&e., to wit:

\section{BASEMENT STORY.}

Store No. 1 is 18.4 in width by 50.0 in length.

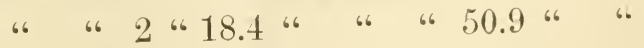

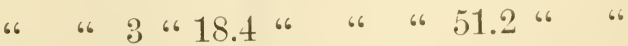

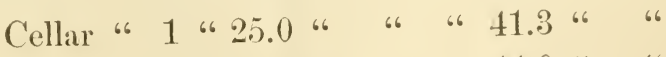

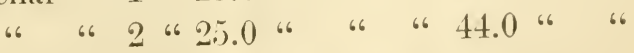

Engine and Boiler Room 14.6 by 36.8 . 
These stores vary in height, conforming to the grade of Bromfield Street.

\section{FIRST OR STREET STORY.}

Store No. 4 is 2.5 .0 in wilth by 41.9 in length.

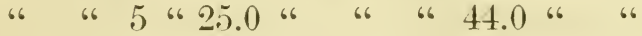

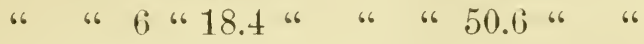

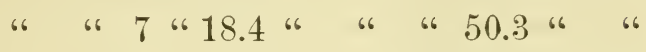

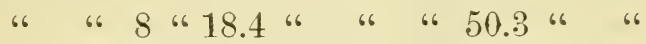

Room for Storage 15.0 by 36.9 .

These stores also vary in height, from 14 feet, least, to $18 \frac{2}{2}$ feet, greatest height, according to the grade.

\section{SECOND STORY.}

Hall, 51 feet by 57 feet.

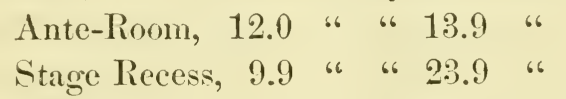

Two Rooms for officers of the Association, 18.6 × 20.6 and $20.9 \times 30.6$, respectively.

The height of these rooms is 17 feet in the clear.

THIRD STORY.

Large Hall, $\quad 50.6$ by 77.9 , height 26 feet.

Stange Recess, $\quad 9.9$ " 23.9

Lobby, $\quad 11.0$ " $\quad 25.0$

Ante-room in rear of Hall, $12.0 \times 13.9$, with another room of corresponding dimensions in the half story above.

The interior of the two halls is of a style of finish and decoration which aceords with the external character of the edifice in erery respect. The lower or smaller hall is finished with pilasters of the Ionic order, sustaining beans on the ceiling, by which it is divided into panelled compartments, - the walls being decorated also with panelling, disposed in suitable divisions. 'The upper hall hats a graceful coved eciling, resting on a deep Ionic comice with modillions, - the face of the pilasters carrying the same being enriched with Arabesque festoons, modelled in high relief. The walls are datoed up as high as 
the sills of the windows, and the doorways leading to anterooms and staircase are ornamented with rich architraves with pedimented heads. The pranels between the crosi-beams on the ceilings, are ornamented with bold mouldings, and with drops at the intersections. The effect of the whole when eompleted will be rich and attractive, and the hall will doubtless be greatly in request for concerts, lectures, and other public oceasions requiring a central and convenient locality.

The external style and appearance of the building are of a dignified and monmmental character, and well calculated for imposing effect. The front extends 55 feet, on Tremont Street. and is divided into three general divisions, or bays. The centre of these is decorated with an order of coupled columns, repeated in pilasters, behind, and carried through the three stories-Doric in the lowest, Ionic in the second, and Corinthian in the third or upper story. A rich composed cornice crowns the whole façade, surmounted by a central attic, as a pedestal for a superb figure of Ceres, cut in white granite, from the celebrated antique in the Vatican, as given in the Museo Pio Clementino, p. 27. The angles of the front are decorated with projecting piers, cut with rich, rermiculated quoins, and forming bases at the top of the entrance story for two other figures, one of Pomona, and one of Flora, the latter copied from the renowned Flora Farnese at Naples. These elegant works of art form, it is believed, the first examples of statuary of a high order of excellence ever placed in similar positions in this country.

The style displayed in this costly and elegant design is one which, it is believed, accords well with the character and requirements of such a structure. It will at once be recognized by all those conversant with such matters, as the prevailing method of modern Europe; a style, which the taste of the present Emperor of France, in particular, has so largely illustrated in most of the modern works of the French capital. From its great intrinsic beauty, not less than from its extreme readiness of adaptation to the wants and uses of the present day, it has attained, under the general title of the lienaissance, 
universal popularity in Europe, and in the chief cities of our .own country. Derived originally from Italian sources, and particularly from the later edifices of the Venetian Republic, it has now been so successfully naturalized elsewhere as to have become the prevailing manner for most of those important public edifices, which are destined to be regarded as the best architectural records of our time, by posterity. A situation so prominent as that of the Horticultural Hall, certainly demands a graceful and harmonious style of design, and it is hoped that the building now in process of erection will stand as a fair memorial of our present advancement in architectural knowledge and taste.

Messrs. G. J. F. Bryant and Arthur Gilman, architects, and superintendents of the erection of the building, are so well known, as gentlemen of experience and taste, that any commendation would be superfluous. They have made all the internal arrangements, agreeably to the views and requirements of the Committee, and the external character of the edifice will show their taste in harmony of details, beauty of proportion, and general expression of design. 